\title{
Transformasi Visual Tokoh Mahabharata dalam Sejarah Komik Indonesia
}

\author{
Wagiono Sunarto \\ Institut Kesenian Jakarta \\ Jln. Cikini Raya 73 Jakarta 10330
}

\begin{abstract}
The great epic of Mahabharata was created through a long period of time in the eastern Punyab region, India. The process of writing was initiated around 300 BC, and in 7 centuries the book was developed by many generations of writers until the final stage which consists of about 10.000 celokas in 18 parwas. After initial stages of development, the great epic continued to spread to other countries and regions, especially to cultures which were influenced by Hindu's or Budha's civilization, including Indonesia (Java, Bali, Lombok, and other regions). In Indonesia, the story was rewriten, reinterpreted and readapted over and over into many spreading cultures and eventually transformed into many forms of visual and performing arts. The long proccess of construction and reconstraction of the story and the characters was a very interesting cultural proccess which is still in progress in our time. The phenomena could be observed in the adaption of the story in the history of Indonesian Comic Books, particullary in the transformation of visual styles in some of modern comic book examples. This visual transformation reflects the change of cultural values and communication circumstances in particular time of history, which in turn change the world's view of the creator in respons to, and relevant with the value changes of the society.
\end{abstract}

Keywords: Visual transformation, Indonesian comic history

\begin{abstract}
ABSTRAK
Epik besar Mahabharata tercipta melalui jangka waktu yang panjang di bagian timur wilayah Punyab, India. Proses penulisannya dimulai sekitar 300 SM, dan selama 7 abad buku tersebut dikembangkan oleh berbagai generasi penulis sampai pada tahap akhir yang terdiri atas sekitar 10.000 celoka dalam 18 parwa. Setelah tahap awal pengembangannya, epik besar tersebut terus menyebar ke negara-negara dan daerah-daerah lain, khususnya ke masyarakat yang dipengaruhi oleh kebudayaan Hindu atau Budha, termasuk Indonesia (Jawa, Bali, Lombok, dan daerah lainnya). Di Indonesia, cerita tersebut ditulis ulang, ditafsirkan dan diadaptasi kembali ke berbagai budaya dan akhirnya ditransformasikan ke dalam berbagai bentuk seni visual dan pertunjukan. Proses konstruksi dan rekonstruksi yang panjang dari cerita dan karakter itu merupakan proses budaya yang sangat menarik yang masih berlangsung hingga masa kini. Fenomenanya dapat diamati melalui adaptasi dari kisah dalam sejarah Buku Komik Indonesia, khususnya pada transformasi gaya visual dalam beberapa contoh buku komik modern. Transformasi visual ini mencerminkan perubahan nilai-nilai budaya dan suasana komunikasi pada waktu tertentu dalam sejarah, yang pada gilirannya mengubah cara pandang respon kreator, serta relevan dengan perubahan nilai-nilai masyarakat.
\end{abstract}

Kata kunci: transformasi visual, sejarah komik Indonesia 


\section{PENDAHULUAN}

Mahabharata adalah epos agung yang lahir di India dan diperkirakan mulai ditulis 300 tahun SM. Selama sekitar 7 abad kisah ini dikembangkan dengan penambahan cerita, syair, dongeng, dan pengayaan karakter sampai akhirnya menjadi naskah yang dianggap asli tulisan Bhagawan Vyasa sepanjang 10.000 seloka dalam 18 Parwa. Pendapat tentang waktu, tempat dan proses penciptaan Mahabharata masih kontroversial, namun disepakati bahwa karena kompleksitas cerita, di mana penulisan sejarah bercampur mitos-mitos kuno India, dan lamanya proses reinterpretasi dan adaptasi selama berabad-abad, maka cerita ini tidak ditulis oleh satu orang. Dengan kata lain, selama berabad-abad telah terjadi suatu konstruksi mitos besar, yang di dalamnya terkandung mitologi, filosofi, pedoman moral, konsep tata negara, dan interpretasi sejarah India (Punjab bagian timur). Hal yang menarik adalah bahwa mitos besar ini kemudian secara wilayah juga berkembang jauh ke wilayah Asia lain dewasa ini, sehingga pada berbagai kebudayaan di Timur mitos ini dianggap sebagai cerita se tempat. Penyebaran atau perembesan tersebut terjadi bersama dengan penyebaran Hindu dan Budha di banyak wilayah di Asia. Proses panjang penulisan Mahabharata, merupakan proses budaya yang menarik. Dalam proses yang berabad abad, suatu struktur cerita yang berbentuk susastra, di-reintepretasi oleh generasi pujangga berikutnya secara terus menerus, baik melalui pengayaan tokoh, pengayaan makna, maupun kaitan wangsa Bharata dengan dunia para Dewa (mitologi) serta kejadian dunia (kosmologi, kosmografi, dan genesis). Pengayaan juga terjadi dalam perpanjangan kisah kemuliaan dan konflik keluarga Bharata sehingga terjadi perang saudara besar Bharata Yudha (apocalypse). Kisah ini ditutup dengan perjalanan Pandawa ke Nirvana, dan kelanjutan generasi berikutnya (rebirth). Seluruh naskah ini diyakini ditulis oleh Bhagawan Vyasa, yang dalam Epos Mahabharata juga dimitoskan, dan dimasukkan sebagai prolog kisah ini.

Epos Mahabharata sebagian bertutur secara naratif dan sebagian didaktik, serta memasukkan berbagai bentuk legenda, mite, yang mengangkat tema filosofis maupun keagamaan. Semua peristiwa sejarah yang terjadi selama beberapa abad itu dirangkai menjadi cerita genesis manusia, dewa dan setengah dewa, raja serta para satria keturunan wangsa Bharata yang akhirnya habis akibat perang akbar antar saudara yang disaksikan para dewa. Beberapa ajaran dalam kisah ini menjadi dialog panjang merupakan bagian tersendiri yang menjadi tuntunan moral dan tanggung jawab satria pada negaranya, yaitu Bhagawad Gita (Leach-Fried, 1960: 664). Di dalam kisah itu berbagai masalah, konflik, perang, dan politik yang terjadi di alam manusia dikaitkan dengan peristiwa-peristiwa dunia para dewa dan setengah dewa. Kompleksnya ajaran moral dan berbagai aturan serta ajaran norma kehidupan menyebabkan Kitab Mahabharata dianggap sebagai ensiklopedia peradaban, kepercayaan dan mitologi serta mitos masa itu (Rines, 1984: 114).

Kisah besar sebanyak sekitar 10.000 seloka dan 18 parwa ini kemudian diadaptasi menjadi berbagai bentuk wacana seni yang lain, dan tersebar melalui proses budaya ke berbagai budaya lain. Selama proses itu, beberapa hal yang menjadi pokok struktur cerita dan tokoh tokoh utama dipertahankan, sedangkan bagian 
bagian lain disesuaikan dengan keadaan budaya setempat.

Di Indonesia, Kakawin Bharata Yudha ditulis dalam bahasa Jawa kuno oleh Mpu Sedah dan diselesaikan oleh Mpu Panuluh pada masa Kediri diperintah oleh Raja Jayabhaya, di awal Abad 12, pada masa yang sama dengan penulisan kitab Kakawin Ramayana, Kakawin Uttara Kanda serta Kakawin Arjuna Wiwaha. Raden Ngabehi Jasadipura menyadur kitab Kakawin Bharata Yudha dari bahasa Jawa kuno ke dalam bahasa Jawa baru, tahun 1775 pada masa Paku Buwana III, Kartasura (Wiryosuparto, 1968: 11-13). Epos besar Mahabharata juga dikonstruksikan pada berbagai daerah serta ditransformasikan ke dalam berbagai bentuk kesenian khas setempat, termasuk dalam berbagai bentuk pertunjukan Wayang serta buku Komik Wayang yang bertema Mahabharata yang juga ada di beberapa negara termasuk negara asalnya, India. Seperti halnya pada proses perkembangan kisah $\mathrm{Ma}$ habharata yang selalu menyesuaikan bentuk dan substansinya untuk tetap aktual pada berbagai perkembangan waktu dan tempat, komiknya pun selalu mengalami proses reinterpretasi berulang-ulang, karena lingkungan budaya yang berubah sesuai zaman. Dalam perubahan interpretasi ini, selalu terjadi penambahan (adaptasi) karena pengaruh unsur budaya baru, serta penghilangan (reduksi) unsur yang lama. Proses ini tercermin dalam transformasi gaya visualnya.

\section{PEMBAHASAN}

\section{Mitos yang mengikuti Dinamika Zaman \\ Proses panjang penciptaan Mahabharata adalah proses pemitosan, yang secara}

terus menerus melalui berbagai zaman melahirkan persepsi baru dan interpretasi baru, yang kemudian dimaknai kembali untuk selanjutnya melahirkan persepsi baru serta interpretasi baru dan seterusnya. Proses ini sejalan dengan teori Barthes dan de Saussure mengenai semiosis berlanjut yang pada waktunya akan melahirkan pemaknaan baru, yang berkembang menjadi mitos baru. Proses pemaknaan berlanjut akan menjadi ideologi (Barthes-de Saussure, 1956: 182). Melalui proses ini sejarah ditransformasikan menjadi persepsi atau ilusi mengenai sejarahnya yang dianggap sebagai kebenaran. Mitos sebagai konsep mengenai kebenaran, atau khazanah kepercayaan, merupakan suatu hal yang luar biasa yang dipercaya sebagai penentu kehidupan (Spence, 1961: 17). Kepercayaan mengenai kebenaran ini selalu berubah sesuai dengan budaya yang hidup pada waktu dan tempat tertentu. Hal ini menjelaskan mengapa Mahabharata menjadi milik masyarakat di lingkungan budaya yang tersebar jauh dari negara asalnya. Mitos adalah pelembagaan sistem tata nilai dan justifikasi sosial dalam suatu masyarakat (Campbell, 1988: 39). Mahabharata mengajarkan bahwa yang baik pada waktunya akan menang, dan jiwa satria akan unggul dalam berbagai konflik manusia. Kisah ini juga melembagakan konsep-konsep kekuatan moral, etika, dan spirit pengabdian yang dapat menandingi kekuatan fisik dan angkara murka.

Tiap-tiap mitos adalah hasil dari penataan ulang, subsitusi, dan permutasi logis unsur unsurnya sendiri (Strauss, 2005: ix). Melalui zaman dan melalui kondisi sosial-budaya tertentu mitos selalu mengonstruksikan makna baru yang lebih sesuai dengan nilai-nilai zamannya, dan 
perubahan pemaknaan baru itu berakibat pada bentuk-bentuk baru yang bisa lebih diterima masyarakatnya. Mitos bukanlah realita objektif materialistik, melainkan anggapan mengenai realita untuk memperkuat eksistensi spiritual dan emosional suatu komunitas pada masa dan tempat tertentu. Mitos bukanlah bentuk komunikasi, namun sebuah sistem komunikasi, suatu tipe wicara (type of speech) yang melahirkan konsep, ide, serta cara pemaknaan (Barthes, 1957: 151). Di sini mitos tidak berhasil memberi pemahaman material mengenai alam dan lingkungannya, namun mitos memberi ilusi kepada manusia bahwa ia memahami alam semesta (Strauss, 2005: 16).

\section{Cerita Wayang}

Wayang atau bayang-bayang awalnya adalah jenis pertunjukan yang mengacu pada Wayang Kulit yang menghasilkan bayangan pada kelir untuk ditonton, namun sebutan ini menjadi nama generik untuk semua pertunjukan yang bertema Mahabharata atau Ramayana. Di Indonesia, khususnya di pulau Jawa, Bali, dan Lombok, kisah epos besar yang awalnya adalah karya susastra berkembang menjadi berbagai bentuk tontonan melalui berbagai jenis wacana cerita. Bentuk wacana pertama kisah Mahabharata yang dikenal adalah kakawin, atau susastra kuno. Naskah klasik kuno tersebut diterjemahkan R. Ng. Jasadipuro ke dalam bahasa Jawa yang baru, yang lebih dipahami. Dari bentuk susastra, kisah ini dikembangkan sesuai pakem, atau 'ditambah' dengan kreasi baru berbentuk lakon carangan. Kisah ini kemudian dialihwacanakan menjadi berbagai bentuk seni pertunjukan dan seni visual serta seni kriya yang mewarnai kehidupan sosial-budaya pada banyak ko- munitas yang tersebar di pulau Jawa, Bali, dan Lombok.

\section{Komik Indonesia}

Bentuk komik yang pertama ada di Indonesia adalah comic strip, yang muncul bersambung pada harian di Jakarta awal tahun 30-an. Pada harian Keng-Po, tokoh Put On yang jenaka dan sial mulai muncul tahun 1931. Put On adalah ciptaan Kho Wang Gie, yang mengangkat tema kehidupan sehari-hari sekelompok warga Jakarta keturunan Tiong Hoa. Dengan bahasa Melayu-Betawi berlogat Cina, komik Put On berhasil memperluas penggemarnya karena teknik gambar yang spontan dan khas serta tema yang secara aktual mengomentari masalah sehari-hari warga Jakarta. Komentar sosial-budaya komik Put On, dapat merefleksikan sejarah politik-ekonomi Indonesia sejak masa Kolonial 1931 sampai masa Konfrontasi Malaysia atau Dwikora tahun 1964. Selama masa itu, Put On menghibur pembacanya dalam Koran Keng Po, Sin Po, kemudian Warta Bhakti yang di-breidel tahun 1965. Jenis comic strip bertema humor seperti Put On juga terlihat di beberapa koran yang berbasis pada pembaca keturunan Tiong Hoa.

Komik dengan tema cerita asli, lahir pada waktu masa pendudukan Jepang, antara lain Roro Mendut, karya J.B. Margono, yang terbit di harian Sinar Matahari, Yogyakarta 1942. Pada waktu yang hampir bersamaan surat kabar Mingguan Ratu Timur yang terbit di Solo juga menerbitkan kisah Mencari Putri Hijau dalam bentuk strip ciptaan Nasrun A.S. Pada awal 50-an, komik pertama yang bertema nasional karya Abdul Salam muncul di Harian Kedaulatan Rakyat yang terbit di Yogyakarta. Abdul Salam yang dianggap 
tokoh awal komik dan karikatur bertema kebangsaan ini mengangkat tema heroik perlawanan rakyat terhadap Belanda dalam Kisah Pendudukan Jogya dan Pangeran Diponegoro. Cerita patriotik kaum tertindas melawan penindas ini mungkin salah satu benang merah menuju Komik Perjuangan Nasional.

Tema 'kebaikan melawan kejahatan' muncul sebagai buku komik lengkap di Indonesia, ketika penerbit Gapura dan Kengpo di Jakarta serta Perfectas di Malang menerbitkan terjemahan produk King Features Syndicate seperti Tarzan karya Sir Edgar Rice Burough, Rip Kirby karya Alex Raymond, dan Phantom karya Wison Mc. Coy. Ketiga judul ini mewakili 3 jenis genre komik yang nantinya memberi pengaruh pada komik Indonesia, yaitu genre manusia-alam perkasa (Tarzan) yang membela lingkungan hutan dari keserakahan peradaban baru, genre detektif cerdas yang berhasil mengungkap kejahatan karena kecerdikannya, dan genre super hero yang membasmi kejahatan karena kekuatan fisik dan ketangkasannya.

Genre manusia-alam melawan keserakahan (Tarzan), terlihat antara lain dalam komik Wiro Anak Rimba ciptaan Kwik Ing Ho serta Djakawana ciptaan S.Ardisoma. Genre Science Fiction seperti Flash Gordon muncul dalam komik Kapten Komet ciptaan Kong Ong, sedangkan genre super hero terlihat antara lain dalam komik Garuda Putih karya Johnlo dan Sri Asih karya R.A.Kosasih. Beragam genre lain lahir sekitar tahun 50-an sampai 70-an yang mengangkat tema kedaerahan serta perjuangan, perang kemerdekaan serta kisah remaja dan legenda lama (Mashab Medan) menandakan masa kejayaan Komik Indonesia. Hal ini menarik karena seakan-akan komik-komik ini menjawab tantangan meluasnya komik Amerika. Segi lain yang menarik, berbagai komik ini juga memperlihatkan upaya komikus untuk membangkitkan identitas dan citra Komik Indonesia.

Pada waktu itu, muncul komik dengan tema epos kepahlawanan yang pertama diciptakan dalam bentuk buku komik berseri di Indonesia yakni Sie Jin Koei ciptaan Siauw Tik Kwie (Otto Swastika) yang dimuat di majalah Star Weekly sejak 1954. Epos heroik Sie Jin Koei dikomikkan berdasarkan terjemahan Oey Kim Tiang ke dalam bahasa Hokkian. Cerita aslinya bernama Xue Rengui, ciptaan Zhang Guobin tahun $649 \mathrm{M}$, mengenai prajurit desa yang mengabdi pada jenderal Zang Shigui dari Dinasti Qing. Keberanian dan ketangkasannya berperang dalam berbagai medan menyebabkan prajurit Xue Rengui diangkat menjadi jenderal kepercayaan Kaisar. Kisah ini kemudian meluas dalam berbagai versi sehingga akhirnya sampai ke Indonesia. Seperti halnya Mahabharata, Xue Rengui mengalami proses transformasi dan reinterpretasi berulang-ulang dalam melahirkan berbagai wacana cerita. Sie Jin Koei kemudian menjadi awal sebuah genre penting perkomikan Indonesia, yaitu Komik Silat.

Pada awal tahun 50-an lahir genre penting yang juga dianggap asli Indonesia, yaitu Komik Wayang berbasis kisah Mahabharata dan Ramayana yang sebelumnya dikenal dalam berbagai bentuk pertunjukan seni tradisional, menjadi bentuk buku komik.

\section{Komik Wayang}

Melalui proses penyebaran dan akulturasi budaya, selama berabad-abad epos besar Mahabharata mengalami transformasi bentuk dan substansi karena proses re- 
interpretasi pemaknaan dan penyesuaian nilai-nilai dengan kondisi sosio-kultural setempat. Dalam proses ini, struktur dasar dan pertokohan utama cerita selalu dipertahankan, namun interpretasi makna, garapan bentuk, teknik penyajian serta sistem penceritaan (story telling) selalu berkembang sesuai dengan adat dan sistem komunikasi setempat. Seni yang tadinya secara eksklusif hanya dinikmati dan dipahami oleh para raja, kaum bangsawan, dan para pendeta ini, kemudian juga berkembang menjadi seni folklorik yang populer di semua kalangan. Upaya memopulerkan Wayang untuk menjangkau kalangan yang lebih luas, merupakan hal yang universal dan umum terjadi pada karya karya klasik. Di Indonesia, fenomena ini terlihat dalam lahirnya Komik Wayang yang segera saja menjangkau banyak kalangan.

Sebelumnya, kisah Mahabharata hanya dapat disaksikan melalui pertunjukan Wayang Kulit, Wayang Golek, Wayang Orang, dan berbagai bentuk pertunjukan Wayang yang lain atau didengar melalui siaran radio. Pemaknaan yang berat dan filosofis dalam Wayang, walaupun telah dibungkus dalam seni tari, musik, busana, dan teater tradisi yang menarik, masih terlalu susah untuk dipahami oleh sebagian masyarakat, terutama anak-anak. Pada masa gaya kehidupan kota sudah menggantikan gaya hidup perdesaan di banyak daerah, dan pada saat yang sama media komunikasi berkembang, seni populer melalui media cetak mengisi kebutuhan informasi dan hiburan. Upaya memopulerkan cerita Wayang melalui komik memang berhasil menyebarluaskan pemahaman mengenai kisah besar Mahabharata (dan Ramayana) serta lakon turunan atau carangan-nya. Apabila moral ceritanya adalah tentang kebaikan dan budi luhur pada akhirnya akan memenangkan pertarungan dengan yang batil, hal itu jelas dapat dilakukan karena basis penggemar yang luas, dan fanatisme penggemar yang tinggi. Pada masa itu, suasana kecanduan komik Indonesia, mungkin sama dengan penggemar manga di Jepang. Namun seorang pengamat komik Indonesia, Marcel Boneff melihat bahwa konsekuensi dari perluasan populasi pemahaman kisah klasik Mahabharata dan Ramayana melalui komik, disertai dengan pendangkalan makna. Membandingkan dengan pertunjukan Wayang Kulit, Boneff menuliskan; "di wilayah kelabu, dalang bermain dengan hebatnya, ia selalu berujar penuh nuansa, dengan satu kata, dia mampu mempertanyakan kembali masalah rumit. Bayangan menampilkan misteri dan kerumitan hidup, mengundang orang untuk keluar dari batas penampilan". Oleh karena itulah, sebagai kekuatan peringatan unggul dari bentuk-bentuk lain. Di sisi lain komik yang dengan beberapa garis menghentikan gerakan jiwa, tidak mungkin menyaingi dalang. Dengan penanya yang selalu terlalu realis, komikus membersihkan 'imajinasi' (Boneff, 1998: 102). Sejak masa Majapahit sampai masa Kesultanan Islam di Jawa berlanjut sampai sekarang di Jawa dan Bali pertunjukan Wayang Kulit juga merupakan salah satu bentuk upaya memopulerkan cerita Klasik untuk dipertontonkan bagi rakyat. Pemaknaan kisah dan peristiwa-peristiwa yang berlapis-lapis dalam pertunjukan Wayang Kulit, menjadi semacam sistem pendidikan di mana penonton memahaminya setelah menonton berulang-ulang sejalan dengan bertambahnya usia dan pengalaman hidupnya. Pemahaman yang lebih utuh tidak dapat diperoleh hanya dengan sekali menonton. 
Memasuki zaman modern, cerita Wayang Kulit juga disiarkan oleh RRI secara rutin.

Sistem pendidikan watak dan moral melalui pertunjukan yang menghibur ini pada dasarnya sama dengan pada komik, namun komik adalah media cetak modern, yang ditujukan pada pembaca urban yang gaya hidupnya lebih dinamis dan cepat sehingga segala sesuatu harus dimengerti dengan cepat. Cerita komik bisa dipahami dengan sekali baca, tanpa banyak perenungan.

Komik Wayang mereduksi pemaknaan klasik karena berurusan dengan pembaca muda dari berbagai usia dan kondisi sosial-ekonomi. Komik Wayang mentransformasikan produk monokultur menjadi multikultur. Seperti terjadi pada berbagai jenis seni populer yang bertema epos atau perjuangan heroik, struktur utama cerita akhirnya direduksi menjadi baik melawan jahat, protagonis melawan antagonis. Kedua polar tokoh-tokoh karakter ini memudahkan jalan cerita dan dialog, dan hal-hal yang menghibur atau menimbulkan sensasi (seperti perkelahian, perang, misteri, kematian dan humor) diberi porsi besar.

Komik Wayang Indonesia dirintis oleh R. A. Kosasih, S. Ardisoma, Oerip, Suherlan, N. A. Giok Lan, dan lain lain. Dari semua itu, yang dianggap berjasa menyebarluaskan seni klasik Wayang ke dalam bentuk populer adalah R. A. Kosasih dan S. Ardisoma, keduanya berdomisili di Bandung. R. A. Kosasih menciptakan Mahabharata sebanyak 22 jilid, Bharatayudha sebanyak 5 jilid, Pandawa Seda sebanyak 4 jilid, dan Parikesit sebanyak 4 jilid. Ardisoma menciptakan Wayang Purwa yang memberi penjelasan mengenai kisah awal para dewa dan keluarga Bharata sebanyak 22 jilid. Ia juga menciptakan kisah awal
Ramayana serta Arjuna Sasrabahu dan kisah lain (Iwan Gunawan dan Zeffry, 1998: 22). Kedua komikus ini menciptakan repertoar pemahaman dasar Mahabharata dan Ramayana sehingga dipakai menjadi acuan oleh generasi komikus lain sampai sekarang.

\section{Transformasi Visualisasi Komik Mahabharata pada ke-4 Komikus Wayang}

Visualisasi tokoh Mahabharata selalu mengalami perubahan gaya bentuk maupun cerita, sesuai dengan kaidah yang ada pada jenis tontonannya, keadaan dan perkembangan teknologi, serta perkembangan kondisi sosial-budayanya. Komik Wayang telah mengukuhkan diri menjadi salah satu genre atau mazhab yang khas dalam sejarah komik Indonesia, dan menjadi referensi bagi generasi komik dalam zamannya atau pada generasi komikus sesudahnya. Sesudah lebih dari 40 tahun, ternyata gagasan untuk melahirkan kembali atau memperbarui Komik Wayang masih terus terpelihara, namun kondisi dunia hiburan dan media sudah sangat jauh berbeda dengan pada masa kejayaan komik Indonesia pada tahun 50-an sampai 70-an. Maka di dalam kajian ini, hal yang menarik adalah membandingkan tampilan visual hasil ciptaan 3 komikus muda, yang terbit 2001 dan 2011 sama dengan para pendahulunya. Contoh yang akan dibahas adalah komik Mahabharata ciptaan Kosasih mewakili genre komik klasik Wayang. Komik Pandawa kreasi baru ciptaan Bambang Irawan dan Harry, Komik Baratayuda karya studio Caravan di Jakarta 2011 dan Garudayana karya Is Yuniarto di Jakarta 2011. 
Komik Mahabharata Ciptaan R.A. Penggambaran busana dan atribut atau Kosasih asesoris juga disederhanakan, tidak se-

Cerita: Jalan cerita Komik Mahabharata ciptaan kosasih masih cukup ketat mengacu pada pakem cerita klasik seperti pada pertunjukan Wayang Tradisional, Wayang Golek, Wayang Orang, atau Wayang Kulit. Sistem penuturan sekuen, sangat runut dengan dialog-dialog yang disederhanakan, namun tetap jelas. Setiap buku menceritakan dengan lengkap suatu penggalan kisah besar dengan lengkap.

Pendekatan visual: Visualisasi adegan digambarkan secara realistik mendekati bentuk dan proporsi manusia normal. rumit penggambaran Wayang Kulit (tatah dan sungging), Wayang Golek, atau Wayang Orang.

Teknik gambar: Halaman kulit digambar dengan teknik outline yang diisi beberapa warna khusus (belum ada teknik separasi warna yang bisa menghasilkan kesan full-color). Halaman Isi digambar dengan teknik pena yang diisi warna hitam putih dengan tinta secara manual. Kesan volume tubuh digambarkan dengan teknik arsir. Sistem garis dan blok hitam dipakai secara sederhana untuk membentuk kesan ruang.
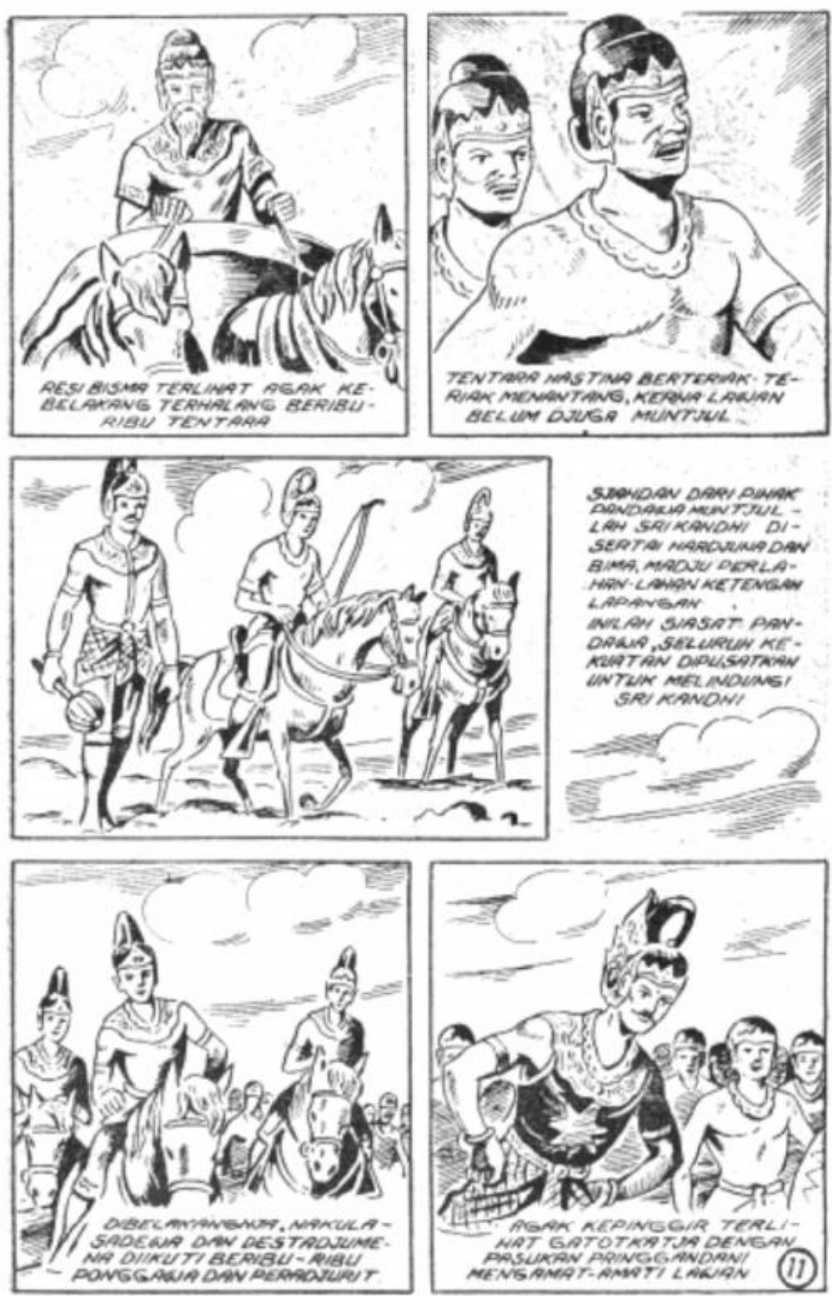

Gambar 1.

Penggambaran tokoh Gatotkaca, Bima, dan Arjuna karya R.A Kosasih, 1957. Mahabharata. Bandung: Melodi. 
Panel: Sistem panel masih teratur dan konvensional. Rangkaian gambar komik ditata dalam kotak-kotak panel yang statis. Sistem pembagian halaman yang teratur ini tidak menjadi bagian dari dinamika cerita. Komposisi dan pembagian panel tidak menjadi bagian dari efek dramatik cerita.

Visualisasi tokoh: Visualisasi tokoh dilakukan dengan anatomi realistik. Perbedaan ukuran dan proporsi tubuh tidak terlalu kontras, mengacu pada realita yang tergambar pada pertunjukan Wayang Orang. Dengan teknik ini, pada umumnya tidak dilakukan penonjolan karakter yang dilebih-lebihkan. Penggambaran tokoh Pandawa dan Kurawa merupakan kombinasi antara Wayang Orang (untuk tokoh baik) dan Wayang Golek (untuk tokoh jahat). Penggambaran ekspresi dan karakter wajah (fisionomi) tidak terlalu dieksplorasi, dan sekadar memperlihatkan watak baik atau jahat. Pembedaan tokoh-tokoh terutama terlihat dari busana dan atributnya (mahkota, topong, gelung, praba, dan irah-irahan), senjata serta gaya dan pelengkap busana lain. Ada kesamaan penokohan dengan gaya visualisasi gambar Mahabharata pada lukisan atau komik India.

Visualisasi lingkungan (setting): Alam cerita juga diciptakan dengan pendekatan realistik, baik alam luas seperti hutan, gunung, dan langit maupun penggambaran bangunan dan istana digambarkan mendekati ilusi yang sesungguhnya. Dengan pendekatan seperti itu, pembuatan latar belakang peristiwa terasa seperti penggambaran backdrop dalam pertunjukan Wayang Orang atau Sandiwara.

Catatan: Referensi komikus R. A. Kosasih adalah pertunjukan Wayang Golek ber- bahasa Sunda, Wayang Wong Priangan yang berbahasa Sunda, Wayang Orang berbahasa Jawa (a.l. Tritunggal di daerah Kosambi yang sudah bermain teratur sejak tahun 50-an di Bandung) serta buku dan referensi tertulis tentang Wayang.

\section{Komik Pandawa Ciptaan Bambang Irawan dan Harry ${ }^{1}$}

Cerita: Kisah Pandawa ciptaan Bambang Irawan dan Harry sangat bebas menginterpretasikan pakem klasik Mahabharata. Ceritanya dititikberatkan pada rangkaian aksi dan laga. Tokoh-tokoh Pandawa yang diangkat tidak seperti dalam cerita klasiknya, selain Bima dan Arjuna yang masih dalam pakem, tiga lainnya adalah Subadra, Brajamusti, dan Krisna. Mereka tidak melawan para Kurawa, melainkan segerombolan tokoh pengacau kota yang mengembangkan berbagai senjata dahsyat. Cara bertutur yang sepotong-sepotong (fragmented) tidak mencoba menjelaskan struktur cerita secara utuh. Seluruh cerita lebih mementingkan aksi laga dan pertarungan baik-jahat. Dialog juga terpotong-potong sekedar memberi tekanan pada dinamika aksinya. Senjata para tokoh yang dalam kisah klasik adalah kekuatan atau kesaktian, diterjemahkan menjadi senjata api berkekuatan besar. Komik ini penuh berisi kemarahan, kebencian, dan dendam.

Pendekatan visual: Komik ini mempunyai pendekatan visual gabungan super hero dan science fiction Amerika (Marvel dan DC). Adegan kebanyakan dibuat close up atau medium close up untuk mendramatisir kekuatan dan ketangkasan tokohnya. Pendekatan visualnya sangat ekspresif dan bebas, tidak terlalu apik dan runut. Penataan efek visualnya dipenuhi asap 
dan ledakan, tidak memberi ruang pada pemahaman alur baik melalui dialog maupun melalui pembacaan gambar.

Teknik gambar: Halaman isi menggunakan teknik hitam putih dengan pena, kuas, dan tinta hitam. Penggunaan teknik kontur dan arsir serta efek-efek ruang dan cahaya sangat terpelihara. Permainan kontras hitam putih juga tergarap baik. Teknik gambar berhasil menciptakan karakter yang kuat dan suasana yang mencekam. Teknik gambar kulit muka merupakan gabungan teknik outline hitam yang diisi warna dengan proses full color, dalam posisi para tokoh saling menumpuk sehingga memberi kesan kekacauan dan bencana.

Panel: Sistem panel yang dipakai sangat bebas, tidak mempunyai pola dasar (basic design) yang teratur. Setiap halaman bisa mempunyai aturan sendiri, sesuai dengan dinamika komposisi halaman dan alur cerita. Panel memberi ruang yang sebebasbebasnya bagi sekuen peristiwa dan aksi yang terjadi.

Visualisasi tokoh: Visualisasi tokoh sudah sangat jauh dari pakem yang ada pada berbagai bentuk Wayang tradisi. Upaya memberi ciri pada tokoh dengan memakai asesori pengenal juga sudah jauh dari pakem serta sedikit sekali dilakukan. Petanda untuk Bima hanya kuku Pancanaka dan kain poleng, selebihnya adalah busana fantasi yang mirip dengan busana super hero atau fiksi seperti star war atau star trek. Pembedaan tokoh dilakukan dengan penggambaran distorsi yang menonjol. Tokoh antagonis digambarkan seperti manusia setengah robot dan jenius sinting yang punya berbagai senjata sinar penghancur. Konsep alih rupa dari wujud manusia menjadi manusia super diwujudkan seperti dalam cerita super hero.
Visualisasi lingkungan: Seperti halnya pada komik aksi jenis super hero, fokusnya lebih pada tokoh dan latar belakang kebanyakan hanya efek visual yang memberi penekanan pada ruang dan dinamika aksi. Ciri lain adalah lingkungan urban modern dengan gedung-gedung pencakar langit yang pada adegan tertentu terlihat samar. Seting utamanya adalah daerah urban, namun deskripsi ruang dan posisi tokoh terhadap ruang tidak jelas, hanya kesan-kesan ada efek tembok atau kesan interior yang tidak proporsional. Gaya seperti ini tidak mencari ketepatan visualisasi lingkungan.

Catatan: Komikus Bambang Irawan dan Harry telah berada pada masa kemajuan industri hiburan baik melalui film-film impor penyebaran DVD maupun melalui media on-line. Pada masa itu terjadi serbuan besar-besaran spill over atau limpahan komik luar dari Jepang, Eropa, dan Amerika. Toko buku dipenuhi komik terjemahan dan program TV Swasta banyak mengangkat program impor. Komikus Indonesia harus terus menciptakan gagasan baru untuk melawan dominasi komik terjemahan yang menguasai pasar Indonesia.

\section{Komik Garudayana Ciptaan Is Yuniarto 2011}

Cerita: Komik ini juga mempunyai konsep cerita yang jauh dari pakem Mahabharata klasik. Dalam setiap episode atau buku, jalan ceritanya tidak runut seperti pada komik ciptaan Kosasih. Sepotong cerita akan diselingi dengan fragmen cerita paralel seperti pada teknik cerita film. Tokoh tokohnya hampir semua sama dengan pakem, namun penggambaran 
karakternya tidak terlalu spesifik. Cerita ini berkembang seperti kisah petualangan yang berbahaya, di mana para tokoh Pandawa atau putranya bertemu dengan monster dalam berbagai bentuk yang harus dikalahkan satu persatu dengan senjata pemungkas atau kesaktian dan kemahiran laga. Disela petualangan seru ini, potongan cerita asli Mahabharata ditampilkan. Komik ini juga memasukkan insert pengetahuan Wayang dan ikonografi perwayangan yang terkait cerita.

Pendekatan visual: Pada dasarnya komik ini dibuat dengan gaya manga yang diisi dengan tema cerita dan tokoh tokoh Mahabharata dan karakter monster da-

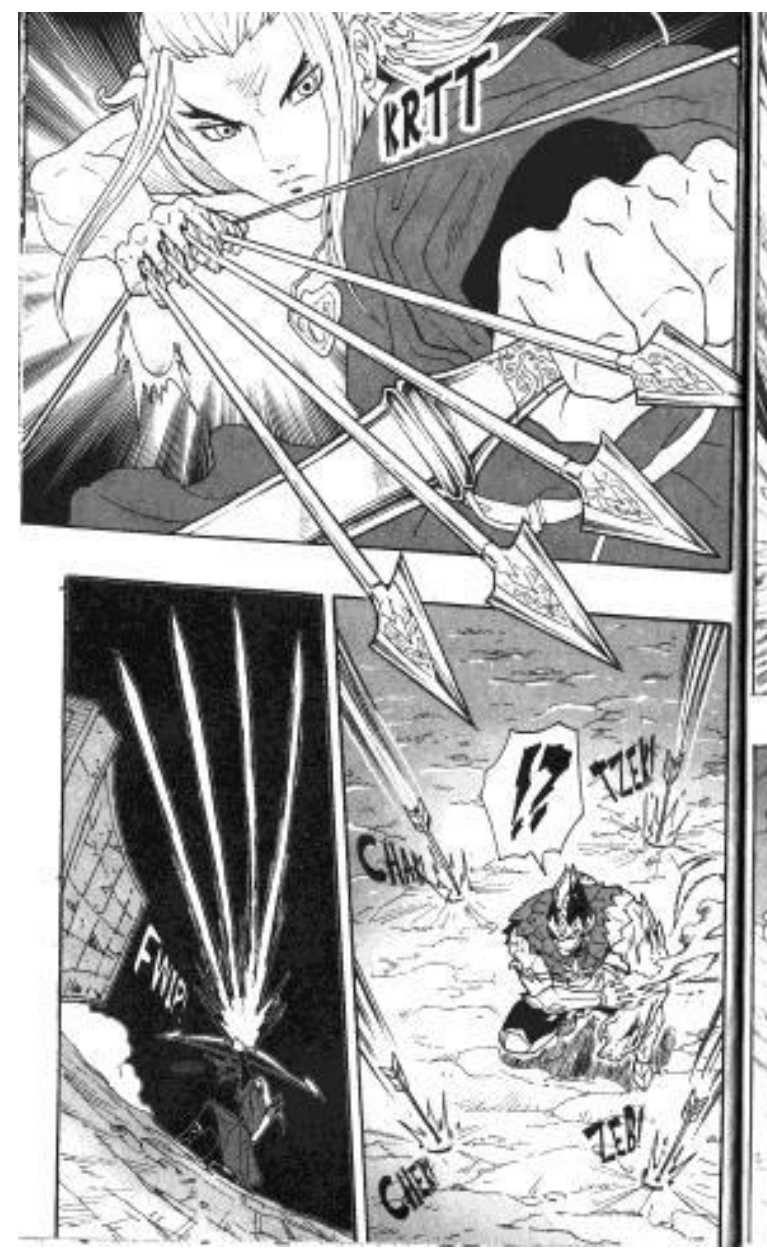

lam berbagai wujud. Pendekatan visual dan kaidah bercerita serta teknik penataan sekuen-sekuennya diadaptasi dari gaya manga. Cara menyusun adegan juga menggunakan teknik manga yang dinamis dan terpotong-potong namun dengan tetap menjaga kontinuitas cerita. Gaya manga terlihat dari variasi titik pandang yang bisa sangat kontras dari extreme close up (misalnya hanya ekspresi kedua mata atau bibir) sampai long-shot (tokoh ditengah alam dalam pemandangan dari jarak jauh), atau perpindahan pandangan burung ke sudut pandang dari tanah. Gaya ini seakan akan memperlihatkan kamera yang selalu bergerak dengan perspektif yang kontras dan dinamis.

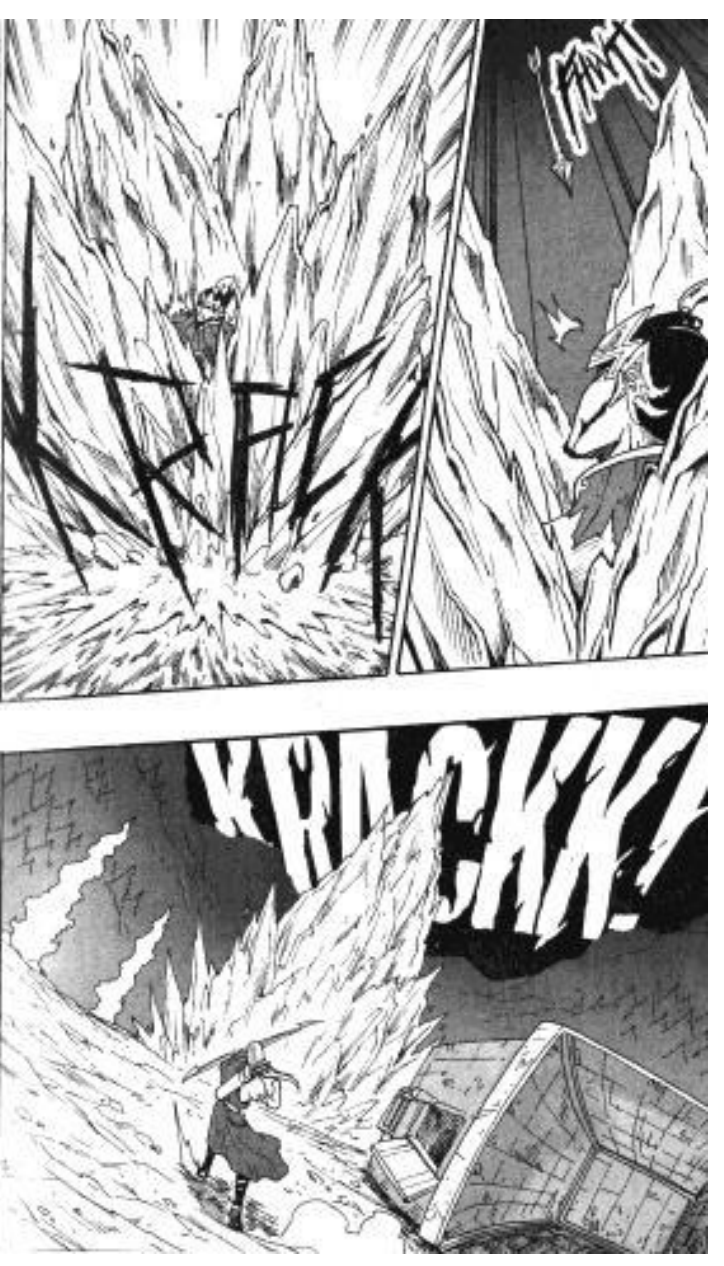

\footnotetext{
Gambar 2.
}

Tokoh Arjuna dalam Garudayana karya Is Yuniarto, 2011, Garudayana. Jakarta: PT. Gramedia. 


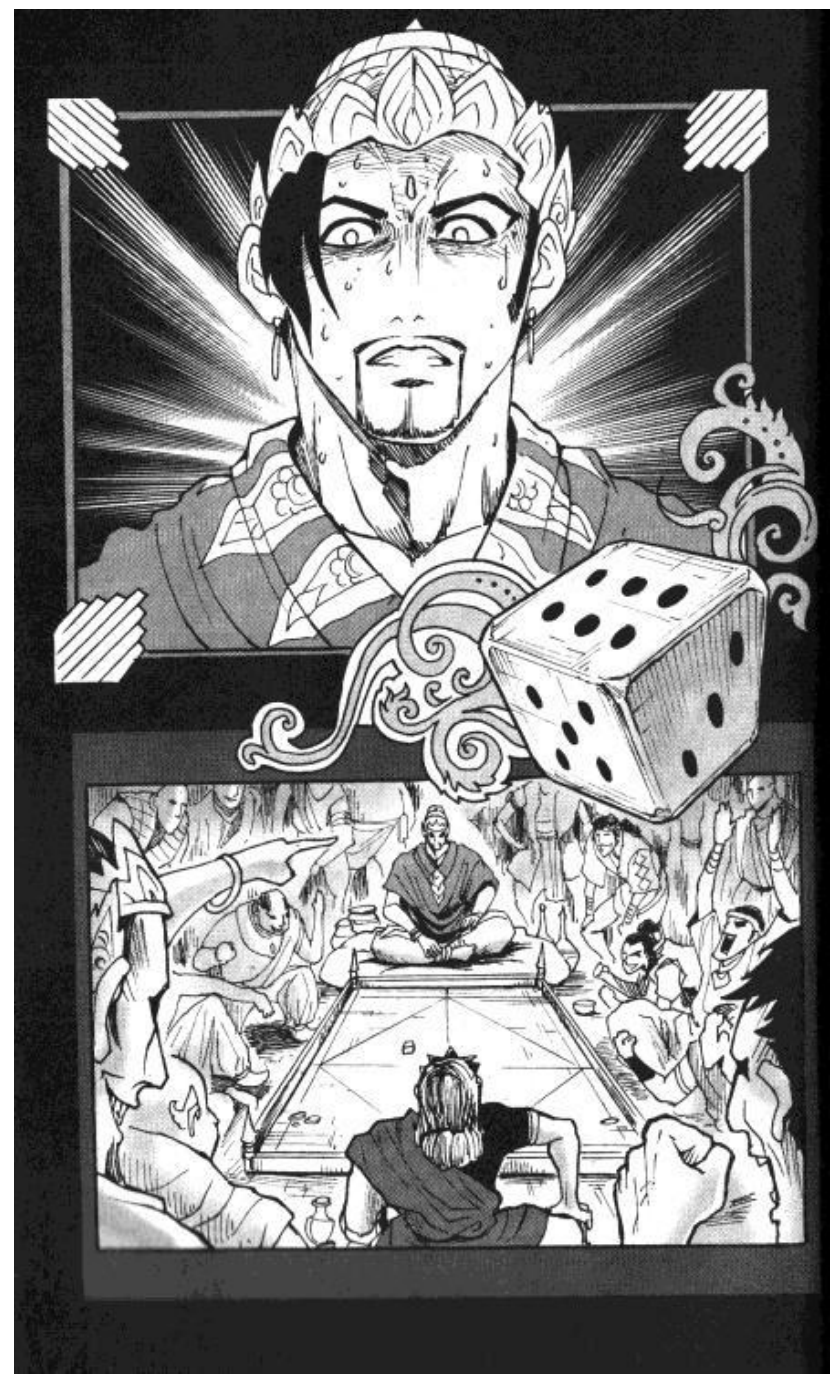

Gambar 3.

Tokoh Yudistira dalam Garudayana karya Is Yuniarto, 2011, Garudayana. Jakarta: PT. Gramedia.

Teknik gambar: Teknik gambar yang dipakai juga memakai gaya manga yang sempurna, yaitu gaya hitam putih memakai outline dan kontur hitam yang halus diisi arsir halus dan gradasi tone yang apik. Kerapihan gaya ini, ditata secara komposisi sehingga tetap dapat memberi definisi ruang yang dinamis dan kesan kecepatan aksi laga yang kuat. Pemakaian tone yang terjaga kadang-kadang diselingi hitam putih yang kontras. Gaya manga terlihat kuat pada visualisasi tokoh perempuan yang imut, bermata lebar seperti kaca dan pakaian yang berkesan street-fashion ABG
Jepang. Tokoh perempuan cantik ini bisa berubah konyol pada momen tertentu. Permainan mimik dan ekspresi wajah lebih penting dari pada definisi karakter.

Panel: Seperti pada umumnya komik manga, permainan bentuk dan posisi panelnya sangat bebas. Pada setiap halaman, sistem panel bisa punya aturan sendiri, namun kontinuitas sekuen tetap dijaga sesuai alur cerita sehingga kita tidak merasakan adanya perbedaan posisi maupun jenis panel. (Panel adalah bagian dari cara bertutur dan memberi kesan ruang). 
Visualisasi tokoh: Visualisasi tokoh dibuat berbeda dengan pakem. Aturan tentang proporsi tubuh sangat bervariasi dan penguatan karakter ditekankan secara ekstrim pada distorsi-distorsi anatomis. Gaya yang dipakai tidak harus konsisten dari tokoh ke tokoh. Pada tokoh tertentu dipakai aturan proporsi mendekati manusia, pada tokoh lain digunakan proporsi super hero sangat ekstrim (kepala kecil dan otot tubuh yang besar), sedang pada tokoh lain dipakai proporsi kartun dengan kepala besar. Busana dan asesori juga digambarkan bebas dengan tidak terikat pakem. Unsur unsur yang ada pada pakem, hanya sesekali dipakai sebagai kode atau simbol pengikat dengan cerita klasik pada Wayang Kulit atau Wayang Orang. Penciptaan karakter lebih ditekankan pada interpretasi pribadi tentang setiap karakter, dikaitkan dengan referensi dari dunia film, televisi, dan game masa kini. Fenomena eklektikisme ini sangat menarik.

Visualisasi lingkungan: Dalam komik ini penggambaran lingkungan dilakukan dengan dua pendekatan, pada aksi laga lingkungan hanya merupakan efek visual yang mendukung gerak, arah dan fokus pertarungan, namun bila diperlukan dalam adegan lain lingkungan didefinisikan secara tiga dimensi dan utuh. Penggambaran setting pemandangan dilakukan dengan distorsi alam yang surealistik, seperti gunung-gunung lancip padat berdekatan, pohon-pohon raksasa dan sudut serta titik pandang yang ekstrim. Dengan cara seperti ini, lingkungan menjadi lebih nyata dan memberi sense of place yang kuat. Penggambaran lingkungan tidak menjadi sekedar backdrop atau background kejadian. Hal yang unik, adalah di tengah suasana manga ini, gedung monumental dan perdesaan di- gambarkan dengan referensi keragaman arsitektur daerah seperti Istana Pagaruyung di Sumatera Barat atau Rumah Adat Karo di Sumatera Utara. Selain suasana fisik, komik ini juga diberi referensi mengenai tokoh terkait dalam gaya Wayang Kulit, serta dekorasi halaman memakai unsur hias tradisi. Dalam komik ini, ada upaya menarik untuk mengangkat sifat multi kultur Indonesia.

Catatan: Komikus Is Yuniarto berkarya pada zaman ITC yang dimanfaatkan baik dalam mengakses berbagai informasi kreatif dan referensi artistik, maupun dalam mengolah aspek visual halamanhalaman komiknya. Walaupun basis konsep visual komiknya adalah manga, ia tetap bisa menata kisah berat Mahabharata menjadi rangkaian aksi dan fantasi yang lancar dan menarik. Unsur Indonesia berhasil disertakan dengan cara yang pas.

\section{Komik Bharatayuda Ciptaan Studio Caravan 2011}

Cerita: Jalan cerita komik ini juga jauh dari pakem klasik, namun masih kuat terlihat bahwa referensi utamanya tetap kisah Mahabharata. Komik ini mempunyai teknik bercerita yang runut. Pokok cerita utama adalah cerita klasik, namun diselingi oleh konflik-konflik anak muda keturunan Pandawa maupun Kurawa, di mana gaya gaul anak muda sekarang tercermin dalam gaya dialognya. Cerita sampingan ini dibuat sangat bebas, sama sekali tidak terikat pakem. Bahasa secara umum juga dibuat dengan referensi bicara masa kini. Penggarapan ceritanya dilakukan konsisten, selesai satu bagian dalam setiap buku. Sampai jilid 6, buku Bharatayudha baru mengisahkan prolog dan peristiwa yang menuju terjadinya perang besar itu. 


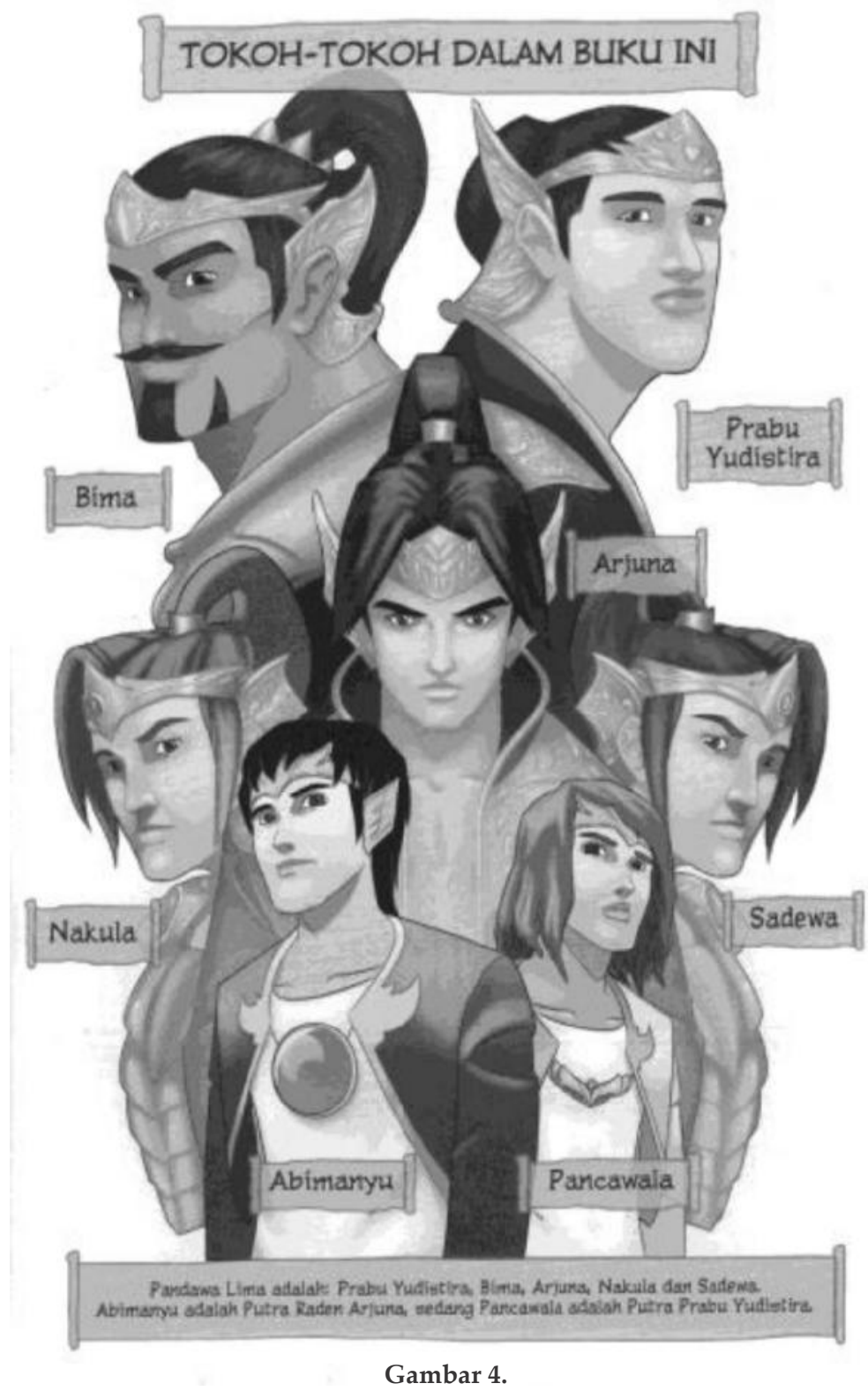

Tokoh-tokoh dalam Bharatayuda karya Studio Caravan, 2011, Bharatayuda. Jakarta: Unima.

Pendekatan visual: Penggambaran cerita ini dilakukan dengan penggambaran realistik yang mendekati suasana dongeng masa lalu. Tokoh maupun dunianya dibuat volumetrik dan 3 dimensi menggunakan teknik warna penuh sampai ke sentuhan nuansa dan gradasi yang halus. Definisi bentuk dan ruang tidak bergantung pada outline dan arsir tetapi dengan kekuatan warna dan gradasinya, dari warna tebal sampai yang paling tipis, suasana dongeng, realistik. Gaya yang dipakai mengingatkan pada pendekatan Disney dan komik serta manga dan anime klasik Jepang yang dipengaruhi Studio Disney. Dengan teknik ini maka adegan laga yang keras tidak menjadi sadis atau kejam. Penggambaran Krisna Tiwikrama, walaupun besar dan garang, tetap digambarkan dengan lembut. Gaya gambar dongeng yang lembut ini sesuai untuk buku anak-anak. 


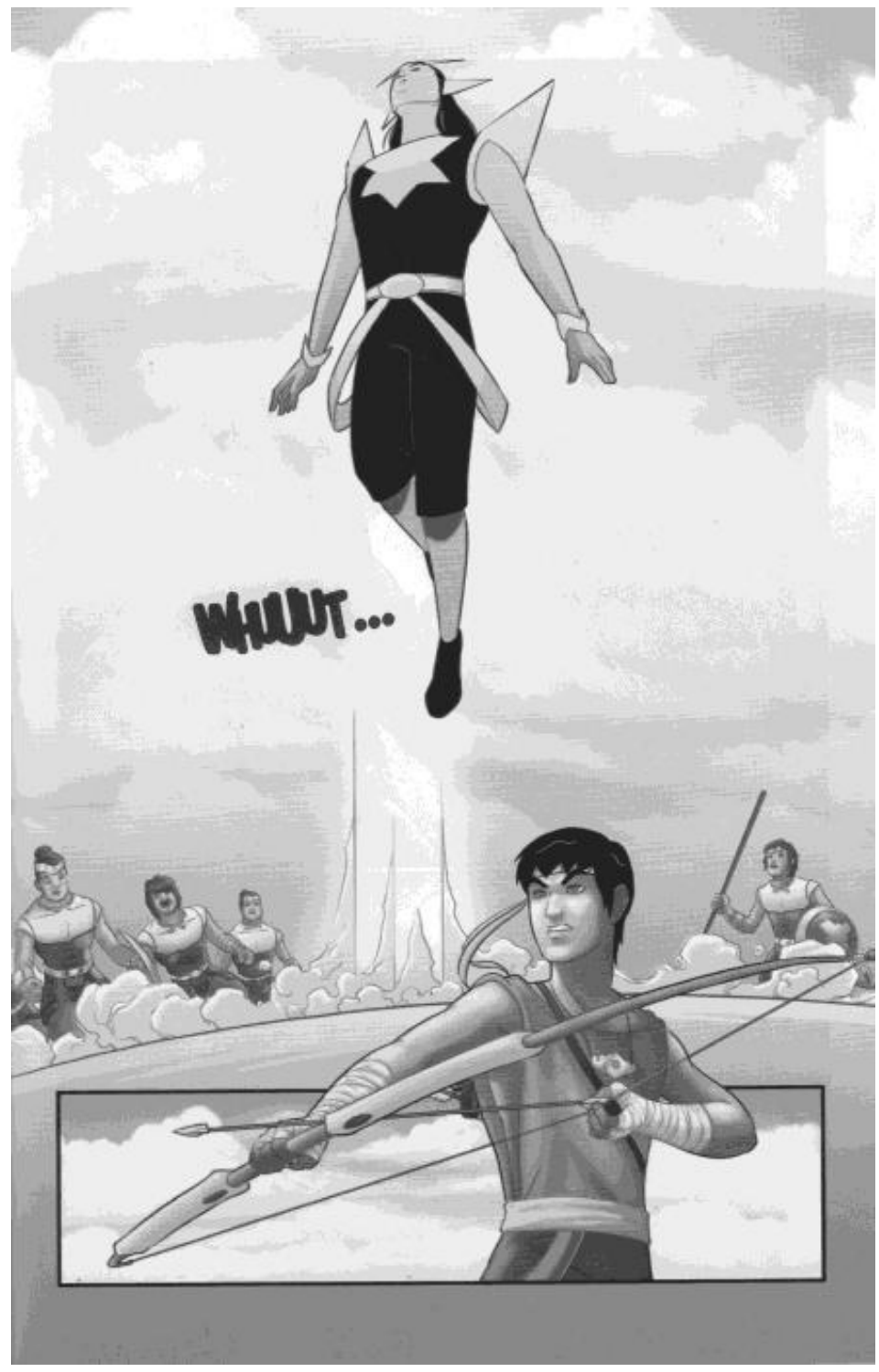

Gambar 5.

Tokoh Gatotkaca karya Studio Caravan, 2011, Bharatayuda. Jakarta: Unima.

Teknik gambar: Teknik gambar warna penuh ini didekatkan pada kesan realistik yang penuh, dari halaman ke halaman. Setiap suasana diperkaya dengan permainan warna dan cahaya halus, yang mendekati warna alam sesungguhnya, dengan distorsi kalibrasi warna untuk menciptakan suasana dongeng.

Panel: Sistem panel yang konvensional dan teratur, membuat pembaca memusatkan perhatian pada gambar-gambar yang dibuat konsisten. Panel hanya berperan sebagai bingkai untuk memberi ruang pada aksi cerita. Pada dasarnya sistem panelnya teratur, dengan pengecualian tertentu pada waktu dibutuhkan. Panel tidak dijadikan unsur bertutur, dan hanya dipakai untuk mengorganisasikan serta menjaga kontinuitas rangkaian cerita dan aksi.

Visualisasi tokoh: Pendekatan visual pada penggambaran karakter dilakukan mendekati keadaan manusia normal. Pro- 
porsi para tokoh tidak banyak didistorsi atau distilasikan menjauhi proporsi normal. Pada penggambaran karakter, ada upaya kuat untuk mendefinisikan watak dan perangai setiap tokoh, bukan sekedar baik dan jahat mendekati normal, distorsi tidak banyak. Interpretasi karakter baik. Setiap tokoh tampak didefinisikan mendekati pakem perwayangan klasik, walaupun busana dan asesorisnya tidak terlalu terikat. Atribut penanda tokoh disederhanakan dan di-redesign sesuai suasana buku, tidak dipaksakan pada semua tokoh.

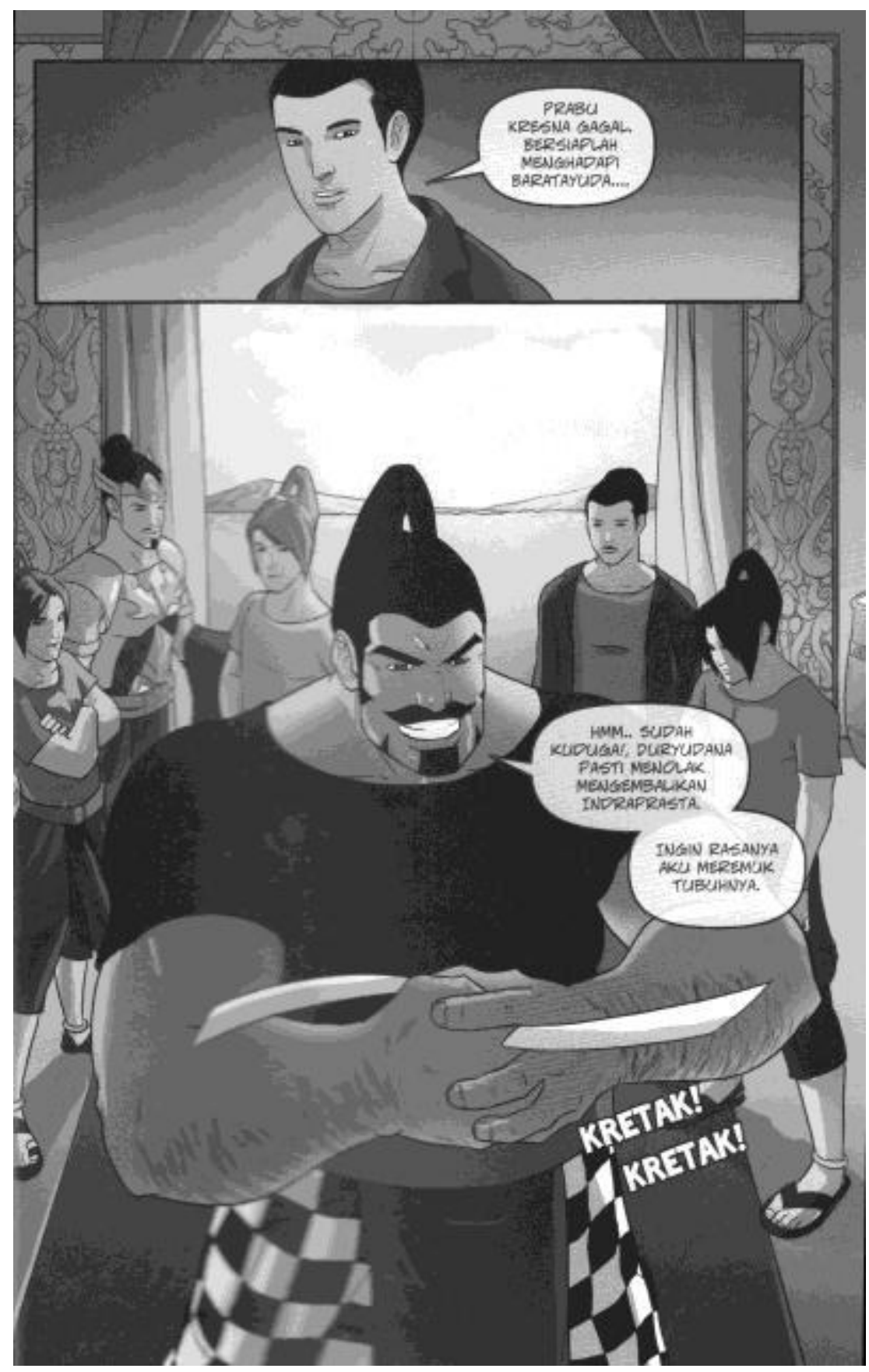

Gambar 6. Tokoh Bima dan Pandawa dalam Baratayuda karya Studio Caravan, 2011, Baratayuda. Jakarta: Unima. 
Catatan: Alam dongeng yang banyak terlihat pada buku klasik anak, menjelaskan salah satu target pasar komik ini. Dalam desain tata muka dan tata rupa serta kualitas cetak, terlihat bahwa komik ini sudah memenuhi persyaratan untuk bersaing dengan komik terjemahan di negeri sendiri. Komik ini tidak digarap oleh satu orang, melainkan suatu grup di studio yang bekerja sesuai sistem manajemen produksi yang baik. Setiap buku ditangani oleh tim yang berbeda dengan pengaturan tugas yang juga apik. Buku ini adalah salah satu contoh kerja kelompok yang tertata baik menghadapi persaingan dalam Industri Kreatif, dengan tujuan dan target usaha yang jelas.

\section{PENUTUP}

Suatu mitos akan menggali material dan memperbarui dirinya terus menerus sesuai dengan lingkungan budayanya. Mahabharata, melalui masa transformasi yang terus menerus dari naskah asli di India, menjadi berbagai produk budaya alih-wahana pada berbagai tempat dan zaman. Dalam perjalanan ruang dan waktu, kisah besar ini juga melalui rangkaian akulturisasi dan rekonstruksi yang terus menerus sampai ke masa kini, di tempat yang jauh dari tempat kelahirannya. Seperti uraian Campbell, bahwa mitos akan mengubah dirinya dengan mengambil material yang cocok dan membuang material yang tidak sesuai lagi dengan zamannya. Mitos besar punya kekuatan persisten untuk selalu menyesuaikan diri dan relevan dengan manusia pada zamannya. Contoh kecil kesinambungan karya R. A. Kosasih dengan 3 komikus generasi sekarang jelas memperlihatkan kesinambung- an dalam berbagai perubahan visualisasi Mahabharata.

Komik Mahabharata Kosasih adalah hasil rekonstruksi kreatifnya, menjawab keinginannya untuk melestarikan kisah besar tersebut kepada pembacanya. Sebagai seni populer, semua pertimbangan konseptual dan artistiknya sesuai zamannya dan target pembacanya. Referensi dan alam perbendaharaan R. A. Kosasih dibatasi oleh alam komunikasi dan kesenian Indonesia, terutama Bandung pada masa tahun 50-an sampai 70-an.

Komik Pandawa ciptaan Bambang Irawan dan Harry, 2001, merupakan upaya merombak konsep klasik dan memberi bentuk yang kaitannya dengan pakem klasik sangat sedikit. Sistem bertuturnya juga sangat ekspresif meledak-ledak. Mungkin proses budaya yang terjadi adalah dekonstruksi dan merangkai kembali kepingan konsep lama serta menambahkan konteks baru yang ekstrim, yaitu lingkungan metropolis dengan tingkat kejahatan tinggi dan kelas berat. Kedua komik lain, yaitu Garudayana karya Is Yuniarto dan Bharatayuda karya Studio Caravan, merupakan upaya rekonstruksi dan reinterpretasi yang matang untuk mendapatkan basis penggemar baru yang luas, dan upaya ini sudah memperlihatkan hasil.

Proses rekonstruksi ini menghasilkan reinvensi dan adaptasi pada pasar masa kini. Proses pengembangan kreasi ini terjadi berdasarkan kaidah komik, kaidah Mahabharata dan imajinasi serta fantasi bebas komikus. R. A. Kosasih telah berhasil mengangkat kembali Mahabharata relevan dengan zamannya. Ketiga contoh komik karya generasi muda memperlihatkan bahwa dengan kiat dan kreativitas masing-masing, upaya mengangkat kem- 
bali Mahabharata untuk pembaca masa kini masih relevan dan masih dilakukan melalui berbagai pendekatan.

\section{CATATAN AKHIR}

1 Komik ini adalah pemenang lomba komik Departemen Pendidikan Nasional 1998, diterbitkan oleh Balai Pustaka 2001.

\section{DAFTAR PUSTAKA}

\section{Sumber Tertulis}

Barthes, Roland

1956 Mitologi. Jakarta: Kreasi Wacana

Boneff, Marcel

1998 Komik Indonesia. Jakarta: Kepustakaan Populer Gramedia.

Campbell, Joseph

1988 The Power of Myth. New York: Anchor Book.

1990 Transformation of Myth through Time. New York: Harper Perennial

Claude, Levi-Strauss

2005 "Mitos dan Makna; Membongkar Kode Kode Budaya". Terjemahan Bhs Indonesia oleh L.P.Hok Myth and Meaning: Cracking the Code of Culture, Magelang: Langit Angkasa.

Iwan Gunawan dan Zeffry

1998 "Sejarah Komik Indonesia". Katalog Pekan Komik dan Animasi Nasional 1998. Jakarta: Departemen Pendidikan \& Kebudayaan Republik Indonesia.
Leach, Maria and Fried Jerome.

1960 Standard Dictionary of Folklore, Mithology and Legend, New York: Funk \& Wagnalls Co.

Rines, George Edwin and Frederick Converse

1984 The Encyclopedia Americana. Ensiklopedi Vol 18, 1984, Connecticut: Grolier Inc.

Spence, Lewis

1961 The Outline of Mythology. New York: Fawcet Publication Inc.

Sutjipto Wiryosuparto

1968 Kakawin Bharata Yudha. Jakarta: Bhratara.

\section{Sumber Gambar/Komik}

Bambang Irawan dan Harry

2001 Pandawa. Jakarta: Balai Pustaka.

Is Yuniarto.

2011 Garudayana. Jakarta: PT. Gramedia.

R. A. Kosasih

1956-57 Mahabharata. Bandung: Melodi.

Studio Caravan

2011 Baratayuda. Jakarta: Unima. 